\title{
THE IMPACT OF TOURISM ON GDP GROWTH IN THE EUROPEAN UNION COUNTRIES
}

\author{
Miloš Pjanići (iD \\ Mirela Mitrašević ${ }^{2}$ (D)
}

DOI: https://doi.org/10.31410/tmt.2020.53

\begin{abstract}
Tourism represents one of the most important economic activities for the global economy. Over the last several decades, the tourism industry has been achieving substantial growth and development in the global market, as well as a positive direct and indirect impact on other economic activities. The paper aims to examine the connection between five tourism indicators and the growth of gross domestic product on the example of EU countries in the period from 2001 to 2019. The research included a total of six variables; the gross domestic product being the dependent variable, while the selected five tourism indicators were independent variables. The main aim of the paper is to determine which of the researched tourism indicators have a statistically significant impact on GDP growth. The empirical analysis is based on IBM SPSS linear mixed procedures. The main findings are that business tourism spending (BTS) and domestic tourism spending (DTS) can predict in a statistically significant and positive way the growth of the gross domestic product in European Union countries.
\end{abstract}

Keywords: Tourism, Economy, GDP, European Union.

\section{INTRODUCTION}

$\mathrm{T}$ ourism is one of the most complex economic activities at the global level. The entire social community uses its services and it is often considered to be an essential determinant when analysing the situation in a society (Serban, 2017). The primary purpose of the paper is to assess the impact of international, domestic and business tourism, variations in the number of employees and capital investment in the tourism industry on the economic growth, measured by GDP growth, in 27 European Union countries. The research covers 19 years in the $21^{\text {st }}$ century and, therefore, enables us to make the factual comparison of our research, from a certain distance, with specific researches on the impact of tourism development on economic growth in various turbulent periods encountered by the economies of the countries currently belonging to the EU as well as with the other countries which, according to numerous authors, are interesting in terms of analysing the impact of tourism on the economic growth. The literature comprises the papers that provide empirical evidence that tourism development has a positive effect on economic growth, as well as the studies that could not determine if tourism has an impact on economic growth, or according to which the impact is negative.

Along with the increasing importance of tourism in the economies of certain countries, the spread of theoretical and practical studies in this area have been enabled by more transparent data as well as statistical software allowing fast and accurate processing of a large amount of data.

Faculty of Economics in Subotica, University of Novi Sad, Segedinski put 9-11, 24000 Subotica, Serbia Faculty of Business Economics, University of East Sarajevo, Semberskih ratara, 76300 Bijeljina, the Republic of Srpska 
The paper is interesting since it considers the importance of tourism for European Union countries' economies, as well as the potential economic losses that certain countries, where tourism is a dominant economic activity, would have due to the measures of their government in the period assessed as critical for COVID-19 virus spread.

There are numerous ways to present the development of tourism in a particular country. Since tourism is one of the most important types of service export, the indicator of international tourism development in the paper will be displayed by the percentage of international tourism receipts (IT) in the total exports in a country in the analysed year. According to the World Travel \& Tourism Council in the period 2001-2018, the lowest average value of the percentage of international tourism receipts in the total exports was recorded in the Netherlands $(2.89 \%)$, while the highest one was in Croatia (41.78\%). Since there are still no data on the percentage of international tourism receipts in the total exports for 2019, the Expectation-Maximization (EM) method was used to estimate the missing values.

As tourism encourages the purchase of domestic services and goods, the indicator of the development of domestic and business tourism spending was chosen to present the percentage of expenditure in this economic activity in the gross domestic product. As for domestic tourism spending, the data of the World Travel \& Tourism Council show that the highest average percentage in GDP in the period 2001-2019 was recorded in Germany (8.79\%), and the lowest one in Poland (1.14\%). On the other hand, the percentage of business tourism spending is lower compared to domestic tourism spending and its average percentage in the observed period ranged from $0.24 \%$ for Hungary to $1.28 \%$ for Estonia.

The positive effect of tourism development in a country is reflected in the increase in the number of employees. The statistics in European Union countries display that in 2019 the highest average percentage of employees in the tourism sector in the total number of employees in the analysed period was in Croatia (22.89\%), while the lowest one was recorded in Poland (4.76\%). In this research, we wanted to answer whether variations in employment in tourism in relation to total employment have a positive effect on economic growth.

Given the role investment plays in the economic development of a country, it has a prominent place in economic theory. Furthermore, investment is a basic component of GDP. Therefore, what certainly should not be left out when analysing the impact of tourism on economic growth are the investments in tourism. In the research, investments were calculated as a percentage of total investments in the analysed country. The country with the highest average percentage of tourism investments in the total investments in these 19 years was Greece (14.56\%), while the lowest one was recorded in Belgium (2.19\%).

The abovementioned variables are also key indicators for the tourism sector available at the World Banks and World Travel \& Tourism Council (WTTC) website. To examine whether there is a positive correlation between the selected variables regarding GDP growth, we used linear mixed models analysis. The research demonstrated that the growth of domestic and business tourism spending had an impact on the economic development of European Union countries. 


\section{LITERATURE REVIEW}

Establishing stable economic growth and development, primarily in the countries lacking capital and managing numerous problems such as unemployment, imbalance of payment, disturbed overall macroeconomic stability can be achieved with tourism as one of the fastest-growing economic activities in recent decades. Tourism generates a significant amount of foreign exchange inflows, alleviates the imbalance of payments, generates employment opportunities, increases income by taxing tourists, encourages entrepreneurial activities, encourages the growth of GDP, and improves the overall economic structure (Hundt, 1996).

Tourism as a topic has played a crucial role over the last few years when discussing economic growth and development in many countries worldwide. Initially, tourism used to be viewed as a phenomenon resulting in travelling and vacation for a certain period and not being considered as a possibility for permanent generating a significant amount of income. Nowadays, tourism is viewed in a completely different way, as one of the key factors in the growth and development of many countries (Vanhove, 2005). Many national economies, where tourism participates with the largest percentage in GDP and whose economic growth depends on tourism, have been forced to improve their competitive advantages in the conditions of fierce competition in the international market (Radukić \& Kostić, 2019).

The research conducted by (Holik, 2016) aims to determine the impact of the tourism sector on the economic growth (GDP) of five ASEAN member states (Indonesia, Malaysia, the Philippines, Singapore, and Thailand). The obtained results indicate that international tourism has a positive and significant impact on the economic growth in these countries, with the variables such as tourist arrival, the number of international tourist arrivals, and the exchange rate. Similar research by (MADEN, BULGAN, \& YILDIRIM, 2019) also emphasizes a positive and statistically significant link between tourism and economic growth.

However, the research conducted by (Chou, 2013) gave rather interesting results when stating that the tourism sector did not have an impact on economic growth in three countries: Bulgaria, Romania, and Slovenia. Interestingly, the same research for other countries, such as Cyprus, Latvia and Slovakia confirmed the positive impact of tourism on economic growth, whereas in the Czech Republic and Poland this relationship was negative. A reciprocal relationship between tourism and economic growth was recorded in Estonia and Hungary.

Having analysed the relationship between economic growth and the tourism sector for ten leading world destinations (China, France, Germany, Italy, Mexico, Russia, Spain, Turkey, Great Britain, and the United States), (Shahzad, Shahbaz, Ferrer, \& Kumar, 2017) indicated that the relationship between tourism and economic growth is positive, still, there are considerable differences between these countries through different quintiles of tourism and GDP per capita within each country. These differences between the countries are reflected in the openness of each economy, the participation of tourism in the overall economy of the country, the importance and participation of local companies in the tourism sector, etc.

It is essential to outline certain studies that show the opposite effect, the ones that emphasize the fact that economic growth encourages tourist expansion. This hypothesis is called the tourism-led growth hypothesis indicating that sustainable economic growth contributes and facilitates the development of tourism in a certain country. The more resources become available 
for tourism infrastructure, the more positive the economic climate encourages further development, diversity, and the expansion of tourism activities. International tourists are attracted by the economic vitality and safety of the country (Chen \& Chiou-Wei, 2009). Therefore, the economic benefits of tourism depend on the willingness and ability of countries to provide appropriate favourable conditions for developing tourism (Haretsebe, 2012).

Tourism is one of the most important sectors that encourages the development of the national economy and employs a large number of people. The study conducted by (Manzoor, Wei, Asif, Zia ul Haq, \& Rehman, 2019) indicates the importance of employment in tourism, outlining the positive impact of employment on economic growth. The research including a group of Asian countries in the period from 1995 to 2004 indicates that international tourism receipts have a significant and positive impact on economic growth (Shakouri, Yazdi, Nategian, \& Shikhrezaei, 2017) and (Hajdinjak, 2014).

Considering the impact of international tourism receipts on economic growth in Turkey, as one of the world's most important tourist destinations in the period 1972-2004, (BAL, AKÇA, \& BAYRAKTAR, 2016) it can be pointed out that international tourism receipts created a positive impact on Turkey's economic growth. Furthermore, an increase in international tourism receipts by $1 \%$ led to the economic growth of $0.314 \%$. Similar researches by (Fayissa, Nsiah, $\&$ Tadasse, 2007) were conducted in 42 African countries indicating that tourism receipts and capital investment significantly contributed to the growth of GDP, with an increase in domestic and business tourism spending of $10 \%$ leading to the growth of GDP of $0.4 \%$. Moreover, the research on a sample of SADC countries shows that an increase in tourism receipts by $1 \%$ led to GDP growth of $0.16 \%$. Also, the investment in tourism by $1 \%$ caused GDP growth by $0.29 \%$ (Makochekanwa, 2013). Thus, these studies indicate that there is a two-way link between tourism receipts and economic growth (Ongan \& Demiröz, 2005) and (Massidda \& Mattana, 2012). Interestingly, some studies present the opposite causality between tourism and economic growth (Risso \& Brida, 2009).

While generating wealth and employment, the tourism industry employs over two hundred million people and plays a significant role in increasing employment and foreign exchange inflows in developing countries. The extent to which this impact will be manifested also depends on the application of liberal policy, adequate tax policy and other comprehensive policy measures that could result in a larger proportion of domestic and foreign direct investment (Vijayaragavan, 2014).

Generally speaking, there are three types of employment in the tourism industry. Firstly, direct employment implies employment in tourist facilities resulting from tourism spending. Secondly, indirect employment as a result of employment in the tourism sector, not being a direct outcome of tourism spending, and induced employment which is the result of „multiplicative effects". The impact of employment on economic growth is evident; however, the growth rate is not always of the same standard because certain types of tourism activity have a specific effect on employment since different tourism activities are labour intensive at different levels (Ardahaey, 2011). Over the last couple of decades, huge investments have been made in the tourism industry. However, these investments, in addition to their significant features, also have certain „weaknesses" which indicate that a certain part of the funds from host countries is withdrawn to the home countries of the investors. Thus, in Thailand, as one of the most popular tourist destinations, about $60 \%$ of annual income from tourism „leaves" the country, because tourists spend money in foreign hotels, mostly consume foreign drinks, and a significant part of profits goes to 
investors' home countries. Nevertheless, despite all the above, capital investments in the tourism sector are flourishing year after year, amounting to over 950 billion dollars (Pjanić, 2019).

To achieve the set purpose of the paper and main objective five hypotheses were formed:

$\mathbf{H}_{1}$ : Variations of international tourism receipts has a statistically significant impact on GDP growth.

$\mathbf{H}_{2}$ : Variations of employment in tourism has a statistically significant impact on GDP growth.

$\mathbf{H}_{3}$ : Variations of capital investment in tourism has a statistically significant impact on GDP growth.

$\mathbf{H}_{4}$ : Variations of business tourism spending has a statistically significant impact on GDP growth.

$\mathbf{H}_{5}$ : Variations of domestic tourism spending has a statistically significant impact on GDP growth.

\section{METHODOLOGY}

\subsection{Research design and data description}

The quantitative research design was employed in empirical research conducted for this paper and its hypothesis testing. This kind of research design was chosen because it focuses attention primarily on rigor measurement and discovering of causal relationships between researched variables (Martin \& Bridgmom, 2012).

The 27 member-countries were included in empiric research with 19 years period researched. The period of 19 years was taken into consideration because it allows the building of a predictive model and identification of variables that have a meaningful and statistically significant relationship with an outcome in multiple variable contexts (Rachev, Hochstotter, \& Fabozzi, 2010) and (Focardi \& Fabozzi, 2004).

Data for our empiric research represents secondary data and they were collected from the World banks and World Travel \& Tourism Council (WTTC) database available on the internet (The World Bank, 2020) and (World Travel \& Tourism Council, 2020). A total of six variables were included in the research. Their descriptions, notations, measurements and roles are presented in Table 1.

Table 1. Description of researched variables

\begin{tabular}{|l|c|c|c|}
\hline Variable name & Notation & Measurement & Role of variable \\
\hline GDP growth & GDP & annual $\%$ & dependent \\
\hline International tourism, receipts & IT & $\%$ of total exports & independent \\
\hline Employment in tourism & ET & $\%$ of total employment & independent \\
\hline Capital investment in tourism & CIT & $\%$ of total investment & independent \\
\hline Business tourism spending & BTS & $\%$ GDP & independent \\
\hline Domestic tourism spending & DTS & $\%$ GDP & independent \\
\hline
\end{tabular}

Source: World banks and World Travel \& Tourism Council (WTTC)

As it is presented in Table 1, our dependent variable was gross domestic product growth (GDP) measured on an annual level. Independent variables were international tourism, receipts (IT), expressed as a percentage of country export, employment in tourism as a percentage of total employment (ET), capital investment in tourism as a percentage of total investment (CIT), and 
business tourism spending (BTS) and domestic tourism spending (DTS) expressed as a percentage of GDP. The observation matrix for collected data included 27 countries, six variables and 19 years which give the total number of 3,078 observations. There were missing data for variable IT for the 2019 year. Moreover, the three variables GDP, BST and DTS had negative values in their distributions. Our data-set represents an unbalanced macro longitudinal set because all members of the set were not observed for one year in one case (Das, 2019) and (Liu, 2016).

\subsection{Procedure of data analysis}

Due longitudinal nature of collected data IBM SPSS linear mixed model procedure was chosen for their analysis. This procedure allows identification of three models - independence model without any random effect with main effect design and restricted maximum likelihood option for parameters estimation, random intercept model which employed factorial design and restricted maximum likelihood option for parameters estimation, and random intercept and slope model with main effect design and maximum likelihood option for parameters estimation (Vehkalahti \& Everitt, 2019);(Landau \& Everitt, 2004). Several reasons led us to choose such a procedure. First, it has well theoretical background; second, it allows models with both fixed and time/ subject-varying, covariates and heterogeneity, as well as heterogeneity in intercepts and slopes for random effect model; third it does not treat fixed and random effect models as mutually exclusive choices, but combines them to overcome biases of each separate model (Heck, Thomas, \& Tabata, 2014); (Vehkalahti \& Everitt, 2019); (Liu, 2016); (Hedeker \& Gibbons, 2006); (Fitzmaurice, Laird, \& Ware, 2011); (West, Welch, \& Galecki, 2015).

Before IBM SPSS linear mixed procedure employment, we took rigor exploratory analysis of our data and tested several assumptions characterized for multivariate data analysis.

\section{RESULTS}

\subsection{Preliminary analysis}

The preliminary analysis comprised of fourth parts. The first part was dealing with missing values in variable IT. For solving that problem, we used the missing data substitution technique via Expectation Maximization (EM), available within Missing Value Analysis option in IBM SPSS (Allen, Bennett, \& Heritage, 2014). EM represents an effective technique, often used in missing data analysis which can overcome limitations of other similar techniques such as mean substitution or regression substitution, and it can be applied whenever the data are missing completely at random or not (Schafer \& Olsen, 1998). Moreover, EM is a stable and robust iterative procedure founded on maximum-likelihood estimates (Najim, Ikonen, \& Daoud, 2004).

The result of EM procedure implementation, which substitutes missing values in variable IT, was presented in Table 2.

Estimated values for each country for variable IT in the 2019 year were included in the research.

The second part of the preliminary analysis was testing assumptions for linear mixed models analysis. It means accessing the appropriateness of variables natures, linearity, multivariate normality, homoscedasticity, and absence of autocorrelation, multicollinearity, multivariate outliers and high influential points (Snijders \& Bosker, 2003);(Bordens \& Abbott, 2008). 
Table 2. EM procedure results

\begin{tabular}{|c|c|c|c|c|c|c|}
\hline \multirow{4}{*}{ Country } & \multicolumn{6}{|c|}{ Variable IT } \\
\hline & \multicolumn{3}{|c|}{ Descriptive Statistics } & \multicolumn{3}{|c|}{ EM Estimated Statistics } \\
\hline & \multirow{2}{*}{$\mathrm{N}$} & \multicolumn{2}{|c|}{ Missing } & \multirow{2}{*}{ Means } & \multirow{2}{*}{ SD } & \multirow{2}{*}{ Covariances } \\
\hline & & Count & $\%$ & & & \\
\hline Austria & 18 & 1 & 5.3 & 9.746 & .876 & .767 \\
\hline Belgium & 18 & 1 & 5.3 & 3.293 & .580 & .336 \\
\hline Bulgaria & 18 & 1 & 5.3 & 15.148 & 3.233 & 10.456 \\
\hline Czech Republic & 18 & 1 & 5.3 & 6.139 & 1.639 & 2.687 \\
\hline Denmark & 18 & 1 & 5.3 & 4.214 & .790 & .625 \\
\hline Estonia & 18 & 1 & 5.3 & 11.179 & 3.272 & 10.710 \\
\hline Finland & 18 & 1 & 5.3 & 4.554 & .656 & .430 \\
\hline France & 18 & 1 & 5.3 & 8.564 & .659 & .434 \\
\hline Greece & 18 & 1 & 5.3 & 26.310 & 2.906 & 8.445 \\
\hline Netherlands & 18 & 1 & 5.3 & 2.895 & .980 & .960 \\
\hline Croatia & 18 & 1 & 5.3 & 41.784 & 3.631 & 13.190 \\
\hline Ireland & 18 & 1 & 5.3 & 3.926 & .412 & .169 \\
\hline Italy & 18 & 1 & 5.3 & 7.857 & .716 & .513 \\
\hline Cyprus & 18 & 1 & 5.3 & 25.485 & 8.635 & 74.571 \\
\hline Latvia & 18 & 1 & 5.3 & 5.736 & .931 & .866 \\
\hline Lithuania & 18 & 1 & 5.3 & 5.309 & 1.896 & 3.594 \\
\hline Luxemburg & 18 & 1 & 5.3 & 5.619 & 1.377 & 1.898 \\
\hline Hungary & 18 & 1 & 5.3 & 6.833 & 1.619 & 2.623 \\
\hline Malta & 18 & 1 & 5.3 & 11.615 & 5.078 & 25.795 \\
\hline Germany & 18 & 1 & 5.3 & 3.445 & .2608 & .068 \\
\hline Poland & 18 & 1 & 5.3 & 6.128 & 1.449 & 2.099 \\
\hline Portugal & 18 & 1 & 5.3 & 18.420 & 1.898 & 3.604 \\
\hline Romania & 18 & 1 & 5.3 & 3.414 & 1.011 & 1.022 \\
\hline Slovakia & 18 & 1 & 5.3 & 3.449 & .806 & .650 \\
\hline Slovenia & 18 & 1 & 5.3 & 8.367 & .706 & .499 \\
\hline Spain & 18 & 1 & 5.3 & 16.709 & 1.167 & 1.361 \\
\hline Sweden & 18 & 1 & 5.3 & 4.905 & .569 & .324 \\
\hline
\end{tabular}

Source: author's research

Dependent and five independent variables had continuous characters and metric nature, which satisfied variable nature assumption. Construction of histograms, normal P-P plots of regression standardized residuals and scatterplots on the univariate and multivariate base were employed to access linearity and multivariate normality. They indicate that data met linearity assumption, but fall to meet multivariate normality because they were negatively skewed data. Glejser test, performed by regression of the absolute values of ordinary least squares residuals from the main regression equation on the explanatory variable GDP, was used to test, homoscedasticity. Results of this test for independent variables IT show statistically significant p-value on the level of $\mathrm{p}<.050, \mathrm{~B}(\mathrm{SE})=-.086(.038), \mathrm{t}=-2.287$, which indicate presence of heteroscedasticity (Gujarati \& Porter, 2009). Absence of autocorrelation, multicollinearity, multivariate outliers and high influential points were accessed by calculation of Durbin-Watson statistics, VIF and TOL values, Mahalanobis distance (MD), Cook's distance (CD) and leverage-value (h) (Brooks, 2014); (Meyers, Gamst, \& Guarino, 2013). The result of Durbin-Watson test, $d=1.133$ indicated the existence of positive autocorrelation following the rule that Durbin-Watson statistic has a value between 0 and 4, with values from 0 to less than 2 mean positive autocorrelation and values from 2 to 4 means negative autocorrelation (Sreejesh, Mohapatra, \& Anusree, 2014). Multicollinearity was accessed by calculation of VIF and TOL values. Obtained values VIF $=2.609$, $\mathrm{TOL}=.383$ for independent variable $\mathrm{IT}, \mathrm{VIF}=1.199, \mathrm{TOL}=.834$ for independent variable $\mathrm{BTS}$, 
$\mathrm{VIF}=2.669, \mathrm{TOL}=.375$ for independent variable $\mathrm{ET}, \mathrm{VIF}=1.305, \mathrm{TOL}=.767$ for independent variable DTS, $\mathrm{VIF}=2.065, \mathrm{TOL}=.484$ for independent variable $\mathrm{CIT}$, led to conclusion that multicollinearity is not present (Sreejesh, Mohapatra, \& Anusree, 2014). The existence of multivariate outliers and high influential points was explored by calculation of Mahalanobis distance (MD), Cook's distance (CD) and leverage value (h). The obtained value of $\mathrm{MD}_{(\max )}=34.404$ indicated presence of multivariate outliers, because maximum allowed value of MD for $\mathrm{df}=5$ $\alpha=.001$ is 20.520 (Denis, 2018); (Lomax \& Hahs-Vaughn, 2020). Besides, the calculated MD/ df value was 6.8808 which was greater than the appropriate value of 4 for large samples (Denis, 2018); (Lomax \& Hahs-Vaughn, 2020). Moreover, the calculated value of $\mathrm{CD}_{(\max )}=.054$ showed the absence of high influential points following the rule of thumb that high influential points exist if CD value exceeds 1 (Denis, 2018); (Lomax \& Hahs-Vaughn, 2020). Leverage value h ranges from 0 to 1 , and it represents a measure of how far away the independent variable values of observation are from those of the other observations (Denis, 2018). In this research calculated $\mathrm{h}_{(\max )}=.067$, and following the rule that values close to 1 indicating great leverage, it was concluded that there are influential cases (Lomax \& Hahs-Vaughn, 2020).

The third part of the preliminary analysis was dealing with negative values in the distribution of variables GDP, BST and DTS. This dealing was necessary because some of the common data transformation types, such as natural logarithm, cannot be performed with negative or zero values (Kennedy, 2008). For that purpose, we corrected all negative and zero values by adding the appropriate value of constant $\mathrm{M}$, following recommendations from the literature (Mickey, Dunn, \& Clark, 2004).

The fourth part refers to outliers and violations of assumptions of multivariate normality, homoscedasticity, and the presence of autocorrelation. In accordance with the nature of assumptions violation and our data nature we decided to recode outliers in regard to avoids the loss of a large amount of data following M-estimation technique and then to transform all data by reflecting and logarithm function: $\log 10 \times(\mathrm{K}$ - old variable value), where $\mathrm{K}=$ the greatest possible value of variable +1 (Aguinis, Gottfredson, \& Joo, 2013); (Leys, Delacre, Mora, \& Lakens, 2019); (Tabachnick \& Fidell, 2014).

\subsection{Main finding}

The independence model, random intercept model and random intercept and slope model obtained by IBM SPSS linear mixed procedure are presented in Table 3.

All three models produced by IBM SPSS mixed procedure were statistically significant - independence model Wald $Z=15.906, p=.000$, random intercept model Wald $Z=16.000, p=.000$, random intercept and slope model Wald $Z=15.875, P=.000$. It implied that all models had to be taken into consideration for the best model, but the best model has to be chosen by calculated information criteria (West, Welch, \& Galecki, 2015); (Heck, Thomas, \& Tabata, 2014); (Konishi $\&$ Kitagawa, 2008); (Gurka, 2006). Following the rule of thumb regarding information criteria as the best model we chose Model 3, i.e. random intercept and slope model because it improved fit in -2LL, AIC and BIC values over the previous models. Results obtained in Model 3 showed indicated that variables BTS_transf, estimated on .249090, $\mathrm{SE}=.115674, \mathrm{t}=2.153, \mathrm{p}=.032$, and variable DTS_transf, estimated on $.155744, \mathrm{SE}=.045979, \mathrm{t}=3.387, \mathrm{p}=.001$, pose as statistically significant predictor of depended variable GDP-transf. 
Table 3. Linear mixed procedure models

\begin{tabular}{|c|c|c|c|c|c|c|}
\hline \multicolumn{7}{|c|}{ Independence model } \\
\hline \multicolumn{7}{|c|}{ Information Criteria } \\
\hline \multicolumn{2}{|c|}{$-2 \mathrm{LL}$} & \multicolumn{3}{|c|}{$\mathrm{AIC}$} & \multicolumn{2}{|c|}{$\mathrm{BIC}$} \\
\hline \multicolumn{2}{|c|}{-461.374} & \multicolumn{3}{|c|}{-459.374} & \multicolumn{2}{|c|}{-455.147} \\
\hline \multicolumn{7}{|c|}{ Estimates $^{\mathrm{a}}$} \\
\hline \multirow{2}{*}{ Parameter } & \multirow{2}{*}{ Estimate } & \multirow{2}{*}{ SE } & \multirow{2}{*}{$\mathrm{t}$} & \multirow{2}{*}{$\mathrm{p}$} & \multicolumn{2}{|c|}{ 95\% Confidence Interval } \\
\hline & & & & & Lower bound & Upper bound \\
\hline Intercept & 1.257627 & .043285 & 29.055 & .000 & 1.172587 & 1.342667 \\
\hline IT transf & -.055463 & .034428 & -1.611 & .108 & -.123101 & .012176 \\
\hline ET transf & .036223 & .056386 & .642 & .521 & -.074556 & .147001 \\
\hline CIT_transf & .028846 & .040108 & .719 & .472 & -.049953 & .107645 \\
\hline BTS_transf & .208594 & .113658 & 1.835 & .067 & -.014705 & .431893 \\
\hline DTS transf & .141957 & .045433 & 3.125 & .002 & -.052697 & .231217 \\
\hline \multicolumn{7}{|c|}{ Estimates of Covariance Parameters ${ }^{\mathrm{a}}$} \\
\hline \multirow{2}{*}{ Parameter } & \multirow{2}{*}{ Estimate } & \multirow{2}{*}{ SE } & \multirow{2}{*}{$\mathrm{t}$} & & $95 \%$ Confid & nce Interval \\
\hline & & & & $p$ & Lower bound & Upper bound \\
\hline Residual & .022690 & .001427 & 15.906 & .000 & .020060 & .025665 \\
\hline & Random i & ept mode & & & & \\
\hline & Inform & Criteria & & & & \\
\hline & & & AIC & & & \\
\hline & & & -475.387 & & -44 & 481 \\
\hline & & & Estimate & & & \\
\hline Parameter & Estimate & SF & (2工 & $n$ & $95 \%$ Confid & nce Interval \\
\hline 1 aranter & Lotintate & NL & $t$ & $P$ & Lower bound & Upper bound \\
\hline Intercept & 1.257627 & .043030 & 29.226 & .000 & 1.173089 & 1.342165 \\
\hline IT_transf & -.055463 & .034225 & -1.621 & .106 & -.122702 & .011776 \\
\hline ET_transf & .036223 & .056054 & .646 & .518 & -.073902 & .146347 \\
\hline CIT_transf & .028846 & .039873 & .723 & .470 & -.049488 & .107180 \\
\hline BTS_transf & .208594 & .112990 & 1.846 & .065 & -.013386 & .430575 \\
\hline DTS_transf & .141957 & .045166 & 3.143 & .002 & -.053224 & .230690 \\
\hline & & Estima & Covarian & eters $^{\mathrm{a}}$ & & \\
\hline Parameter & Estimate & SE & 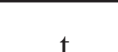 & & 95\% Confid & nce Interval \\
\hline I atanterter & Lstintale & & $l$ & $p$ & Lower bound & Upper bound \\
\hline Residual & .022424 & .001402 & 16.000 & .000 & .019839 & .025346 \\
\hline & & Rando & rcept an & nodel & & \\
\hline & & & mation C & & & \\
\hline & & & $\mathrm{AIC}$ & & & \\
\hline & & & -437.369 & & -428 & 924 \\
\hline & & & Estimate & & & \\
\hline & & & & & 95\% Confid & nce Interval \\
\hline Parameter & Estimate & SE & $\mathrm{t}$ & $\mathrm{p}$ & Lower bound & Upper bound \\
\hline Intercept & 4.679476 & 2.53786 & 1.844 & .066 & -.306628 & 9.665580 \\
\hline IT_transf & -.061445 & .036064 & -1.704 & .089 & -.132299 & .009408 \\
\hline ET_transf & .046276 & .056935 & .813 & .417 & -.065583 & .158135 \\
\hline CIT_transf & .033266 & .040618 & .819 & .413 & -.046536 & .113068 \\
\hline BTS_transf & 249090 & 115674 & 2.153 & 032 & .021827 & .476353 \\
\hline DTS_transf & 155744 & .045979 & 3.387 & .001 & -.065410 & 246078 \\
\hline & & Estima & Covarian & eters $^{\mathrm{a}}$ & & \\
\hline & & & & & $95 \%$ Confid & nce Interval \\
\hline Parameter & Estimate & SE & $\mathrm{t}$ & $\mathrm{p}$ & Lower bound & Upper bound \\
\hline Residual & .022614 & .001425 & 15.875 & .000 & .019987 & .025586 \\
\hline
\end{tabular}

Source: author's research 
Chosen model reliability was accessed by calculation of interclass correlation coefficients (ICC) (Shrout \& Fleiss, 1979);(Johnson \& Koch, 2011). Based on 95\% confidence interval, ICC for random slope and intercept model had a value of .49916, which means that $49.916 \%$ of the variation in variable GDP_transf was due to within-unit differences in the model. Following guidelines for ICC interpretations, the obtained value may be treated as fair (Cicchetti, 1994).

\section{DISCUSSION}

Obtained results confirmed only hypotheses $\mathrm{H}_{4}$ and $\mathrm{H}_{5}$ indicating that business tourism spending (BST) and domestic tourism spending (DST), expressed as a percentage of GDP, in a statistically significant and positive way can predict gross domestic product (GDP) growth in EU countries. Those findings are in accordance with Eurostat data which indicates that the citizens of the EU spent $82 \%$ of their tourism expenditure on trips inside Europe, i.e. $78 \%$ inside the EU (Eurostat, 2020).

Even though international tourism receipts are part of a country's export revenues that are included in the GDP, our results did not confirm the hypothesis that the variations of international tourism receipts have a statistically significant impact on GDP growth. The reason for this can be found in the characteristics of the trends of the selected indicators in the analysed period. Comparing the proportion of international tourism receipts in the total exports in 2018 compared to 2009, it can be noticed that majority of countries recorded a decline and that significant decline was recorded in Malta. The growth was recorded in Austria, Portugal, Romania, Sweden, and Finland with the highest growth. Moreover, it is interesting to compare the trends of GDP growth and international tourism receipts in total exports in 2009 compared to 2008. The data from the World Travel \& Tourism Council (WTTC) indicate that all these countries had negative GDP growth in 2009. Nevertheless, international tourism receipts in total exports in 2009 decreased in Estonia, Ireland, Cyprus, Malta, Poland and Romania, while other countries recorded growth.

The abovementioned results may indicate the need to consider the potential of individual segments of tourism and the need for additional investment which could boost economic growth. The need for further researches in the field of tourism is becoming essential especially due to movement restrictions aimed to slow down the spread of COVID 19 infection. The measures of the governments of the analysed countries led to significant losses in the tourism sector. Moreover, according to the baseline scenario published by the World Travel \& Tourism Council (WTTC) (Council, 2020) a reduction in the number of employees by 18.4 million is expected in European countries in 2020 or $50 \%$ compared to 2019, as well as a reduction of the contribution of the tourism sector to GDP by $\$ 1,000$ billion.

\section{FUTURE RESEARCH DIRECTIONS}

Taking into account the fact that the whole world is affected by the Covid-19 pandemic, which has caused a drastic decline in tourism activity, it will be necessary to review what measures many countries have taken to save the industry since for many of them it is the source of their economic survival. Furthermore, it will be necessary to thoroughly analyse the existing and future consequences of the loss regarding the decline in employment, expenditure, investment and the extent to which all of the above items will affect the decline in overall economic activities in many countries. Undoubtedly, almost all governments will face tough challenges, as well as sat- 
isfaction/dissatisfaction with the measures they will have to take in order to try to save a large number of tourist companies, agencies, hotels, employees, etc. Future researches should be directed towards the analysis of the measures that the countries will take and their final effects.

\section{CONCLUSION}

This paper examines the hypotheses of the impact of the key indicators of the development of the tourism sector on the growth of GDP of 27 countries of the European Union in the period 2001-2019 using linear mixed models analysis. Our empirical results show a statistically significant correlation between business and domestic tourism development and economic growth, still, they do not confirm a statistically significant relationship between the variations of international tourism receipts, the variations of employment in tourism and the variations of capital investment in tourism on GDP growth. We believe that these results can be partly explained by the impact of the global financial crisis on the tourism sector as a significant component of export of certain countries, but also by other indicators that constitute the export and GDP and which are the reasons why, even though export presents one component of GDP, the applied method has not proved that the proportion of international tourism receipts in the total exports of a country can predict the growth of the gross domestic product in a statistically significant and positive way.

The paper was written at a time when numerous restrictive measures were in force, which according to the competent authorities, were considered justified to prevent COVID-19 transmission. These measures significantly reduced travelling, and thus tourism receipts and employment. Since the tourism sector can play a significant role in the economic recovery of European Union countries, future researches should be directed towards the analysis of the measures that countries could take in order to recover and further develop this sector.

\section{REFERENCES}

Aguinis, H., Gottfredson, R., \& Joo, H. (2013). Best-Practice Recommendations for Defining, Identifying, and Handling Outliers. Organizational Research Methods, 16(2), 270-301.

Allen, P., Bennett, K., \& Heritage, B. (2014). SPSS Statistics Version 22: A Practical Guide, Third Edition. South Melbourne: Cengage Learning Australia.

Ardahaey, F. (2011). Economic Impacts of Tourism Industry. International Journal of Business and Management, 6(8), 206-215.

BAL, H., AKÇA, E., \& BAYRAKTAR, M. (2016). The Contribution of Tourism to Economic Growth: A Research on the Turkey. SPRING, 7(1), 1-20.

Bordens, K., \& Abbott, B. (2008). Research Design and Methods: A Process Approach, Eight Edition. New York: McGraw-Hill.

Brooks, C. (2014). Introductory Econometrics for Finance, Third edition. Cambridge: Cambridge University Press.

Chen, C., \& Chiou-Wei, S. (2009). Tourism expansion, tourism uncertainty and economic growth: New evidence from Taiwan and Korea. Tourism Management, 30, 812-818.

Chou, M. (2013). Does Tourism Development Promote Economic Growth in Transition Countries? A Panel Data Analysis. Economic Modelling, 33, 226-232.

Cicchetti, D. (1994). Guidelines, Criteria, and Rules of Thumb for Evaluating Normed and Standardized Assessment Instruments in Psychology. Psychological Assessment, 6(4), 284-290. 
Council, T. W. (2020, October Monday). The World Travel \& Tourism Council . Retrieved from The World Travel \& Tourism Council: (https://wttc.org/Research/Economic-Impact/Recovery-Scenarios-2020-Economic-Impact-from-COVID-19),

Das, P. (2019). Econometrics in Theory and Practice: Analysis of Cross Section, Time Series and Panel Data with Stata 15.1. Singapore: Springer.

Denis, D. (2018). SPSS Data Analysis for Univariate, Bivariate and Multivariate Statistics. New York: John Wiley \& Sons.

Eurostat. (2020, October Monday). Eurostat. Retrieved from Eurostat: https://ec.europa.eu/eurostat/statistics-explained/index.php/Tourism_statistics___expenditure

Fayissa, B., Nsiah, C., \& Tadasse, B. (2007). The Impact of Tourism on Economic Growth and Development in Africa. Tourism Economics, 14(4), 1-21.

Fitzmaurice, G., Laird, N., \& Ware, J. (2011). Applied Longitudinal Analysis, Second Edition. New York: John Wiley \& Sons.

Focardi, S., \& Fabozzi, F. (2004). The Mathematics of Financial Modeling and Investment Management. John Willey \& Sons: New York.

Gujarati, D., \& Porter, D. (2009). Basic Econometrics, Fifth Edition. New York: McGraw-Hill/ Irwin.

Gurka, M. (2006). Selecting the Best Linear Mixed Model under REML. The American Statistician, 60(1), 19-26.

Hajdinjak, S. (2014). IMPACT OF TOURISM ON ECONOMIC GROWTH IN CROATIA. Enlightening Tourism. A Pathmaking Journal, 4(1), 30-51.

Haretsebe, M. (2012). Communities' understanding of tourists and the tourism industry: The Lesotho Highlands water project. African Journal of Business Management, 6(22), 6667-6674.

Heck, R., Thomas, S., \& Tabata, L. (2014). Multilevel and Longitudinal Modeling with IBM SPSS, Second Edition. New York: Routledge/Taylor \& Francis Group.

Hedeker, D., \& Gibbons, R. (2006). Longitudinal Data Analysis. New York: John Wiley \& Sons.

Holik, A. (2016). Relationship of Economic Growth with Tourism Sector. Journal of Economics and Policy, 9(1), 16-33.

Hundt, A. (1996). Impact of Tourism Development on the Economy and Health of Third World Nations. Journal of Travel Medicine, 3(2), 107-112.

Johnson, W., \& Koch, G. (2011). Intraclass Correlation Coefficient, In: Loveric. M. (eds.) International Encyclopedia of Statistical Science. Berlin: Springer-Verlag.

Kennedy, P. (2008). A Guide to Econometrics, Sixth Edition. Malden: Blackwell Publishing.

Konishi, S., \& Kitagawa, G. (2008). Information Criteria and Statistical Modeling. New York: Springer Science+Business Media.

Landau, S., \& Everitt, B. (2004). A Handbook of Statistical Analyses using SPSS. Boca Raton: Chapman \& Hall/CRC Press.

Leys, C., Delacre, M., Mora, Y., \& Lakens, D. (2019). How to Classify, Detect, and Manage Univariate and Multivariate Outliers, With Emphasis on Pre-Registration, Article 5. International Review of Social Psychology, 32(1).

Liu, X. (2016). Methods and Applications of Longitudinal Data Analysis. London: Academic Press - Elsevier.

Lomax , R., \& Hahs-Vaughn, D. (2020). An Introduction to Statistical Concepts, Fourth Edition. New York: Routledge/Taylor \& Francis Group.

MADEN, S., BULGAN, G., \& YILDIRIM , S. (2019). The Effect of Tourism Sector on Economic Growth: An Empirical Study on Turkey. Journal of Yasar University, 215-225.

Makochekanwa, A. (2013). An analysis of tourism contribution to economic growth in SADC Countries. Botswana Journal of Economics, 11(15), 42-56. 
Manzoor, F., Wei, L., Asif, M., Zia ul Haq, M., \& Rehman, H. (2019). The Contribution of Sustainable Tourism to Economic Growth and Employment in Pakistan. International Journal of Environmental Research and Public Health, 16, 1-14.

Martin, W., \& Bridgmom, K. (2012). Quantitative and Statistical Research Methods: From Hypothesis to Results. San Francisco: CA, Jossey-Bass/Wiley.

Massidda, C., \& Mattana, P. (2012). A SVECM analysis of the relationship between international tourism arrivals, GDP and trade in Italy. Journal of Travel Research, 52(1), 93-105.

Meyers, L., Gamst, G., \& Guarino, A. (2013). Performing Data Analysis using IBM SPSS. New York: John Wiley \& Sons.

Mickey, R., Dunn, O., \& Clark, V. (2004). Applied Statistics: Analysis of Variance and Regression. New York: John Willey \& Sons.

Najim, K., Ikonen, E., \& Daoud, A. (2004). Stochastic Processes - Estimation, Optimization and Analysis. London: Kogan Page Science.

Ongan, S., \& Demiröz, D. (2005). The contribution of tourism to the long-run Turkish economic growth. Journal of Economics, 9(53), 880-894.

Pjanić, M. (2019). Economic effects of tourism on the World economy. 4th International Thematic Monograph - Thematic Proceedings: Modern Management Tools and Economy of Tourism Sector in Present Era, 291-305.

Rachev, S., Hochstotter, M., \& Fabozzi, F. (2010). Probability and Statistics for Finance. John Wiley \& Sons: New York.

Radukić, S., \& Kostić, Z. (2019). What is the impact of price factors on sustainable tourism competitiveness? 4rd International Thematic Monograph - Thematic Proceedings: Modern Management Tools and Economy of Tourism Sector in Present Era, p, 169-182.

Risso, W., \& Brida, J. (2009). The contribution of tourism to economic growth: an empirical analysis for the case of Chile. European Journal of Tourism Research, 2(2), 178-185.

Schafer, J., \& Olsen, M. (1998). Multiple Imputation for Multivariate Missing Data Problems: A Data Analyst's Perspective. Multivariate Behavioral Research, 33(4), 545-571.

Serban, C. (2017). The Impact of Tourism on the Global Economic System. Economic Sciences Series, 17(1), 384-387.

Shahzad, S., Shahbaz, M., Ferrer, R., \& Kumar, R. (2017). Tourism-led growth hypothesis in the top ten tourist destinations: New evidence using the quantile-on-quantile approach. Tourism Management, 60, 223-232.

Shakouri, B., Yazdi, S., Nategian, N., \& Shikhrezaei, N. (2017). International Tourism and Economic Growth and Trade: Variance Decomposition Analysis. Journal of Tourism \& Hospitality, 6(3), 1-11.

Shrout, P., \& Fleiss, J. (1979). Intraclass Correlations: Uses in Assessing Rater Reliability. Psychological Bulletin, 86(2), 420-428.

Snijders, T., \& Bosker, R. (2003). Multilevel Analysis: An Introduction to Basic and Advanced Multilevel Modeling. London: SAGE Publications.

Sreejesh, S., Mohapatra, S., \& Anusree, M. (2014). Business Research Methods - An Applied Orientation. Cham: Springer International Publishing.

Tabachnick, B., \& Fidell, L. (2014). Using Multivariate Statistics, Sixth Edition. Harlow: Pearson Education.

The World Bank. (2020, October Monday). The World Bank. Retrieved from The World Bank: https://databank.worldbank.org/indicator/NY.GDP.MKTP.KD.ZG/1ff4a498/Popular-Indicators https://wttc.org/Research/Economic-Impact/Data-Gateway

Vanhove, N. (2005). The Economics of Tourism Destinations. London: Oxford: Elsevier Butterworth-Heinemann, United Kingdom. 
Vehkalahti , K., \& Everitt, B. (2019). Multivariate Analysis for the Behavioral Sciences, Second Edition. Boca Raton: CRC Press/Taylor \& Francis Group.

Vehkalahti, K., \& Everitt, B. (2019). Multivariate Analysis for the Behavioral Sciences, Second Edition. Boca Raton: CRC Press/Taylor \& Francis Group.

Vijayaragavan, T. (2014). Impact of tourism in Indian economy. International Journal of Development Research, 4(12), 2835-2839.

West, B., Welch, K., \& Galecki, A. (2015). Linear Mixed Models: A Practical Guide Using Statistical Software. Boca Raton: CRC Press/Taylor \& Francis Group.

World Travel \& Tourism Council. (2020, October Monday). World Travel \& Tourism Council. Retrieved from World Travel \& Tourism Council: https://wttc.org/Research/Economic-Impact/Data-Gateway 